Article

\title{
Long-Term Educational Sustainability: Educational Innovation in Social Vulnerability Contexts
}

\author{
Ana Tur-Porcar ${ }^{1, *}$, Alicia Mas-Tur ${ }^{2}$ and Elisabeth Malonda Vidal ${ }^{1}$ \\ 1 Basic Psychology Department, Universitat de València, 46010 Valencia, Spain; elisabeth.malonda@uv.es \\ 2 Business Management Department, Universitat de València, 46022 Valencia, Spain; alicia.mas@uv.es \\ * Correspondence: ana.tur@uv.es; Tel.: +34-9638-64562
}

Received: 31 July 2017; Accepted: 8 September 2017; Published: 13 September 2017

\begin{abstract}
This paper investigates the behavior of children from low socioeconomic status families and examines the effects of a socioemotional education program on aggression in children. The results of the program are compared according to the children's gender and age, the family structure, the parents' educational attainment, and social status. The results show that applying socioemotional education programs reduces children's aggression and encourages positive development during adolescence. This positive development fosters open, expressive behavior.
\end{abstract}

Keywords: socioemotional education; aggressive behavior; socioeconomic status (SES); gender; parents' educational attainment; education innovation

\section{Introduction}

School curricula cover numerous subjects with the aim of educating people in all areas of their lives. School curricula also provide students with a comprehensive education to enable their integration within an inclusive, democratic society.

Yet, most curricula are based on traditional subjects such as calculus, geometry, languages, and geography, as well as applied subjects such as physical education, music, and citizenship education. Judging by the rates of school failure in Spain, however, these subjects and the curricula that cover them require thorough inspection and revision.

For example, the Spanish Ministry of Education, Culture, and Sport [1] has reported that, in Spain, school failure is approximately $20 \%$. School failure among boys $(24 \%)$ was higher than among girls $(12.4 \%)$ in 2016 . These figures imply that only $76 \%$ of boys and $87.6 \%$ of girls successfully finish compulsory education. These failure rates are troubling because educational attainment is related to poor access to the labor market and a high unemployment rate (17.22\% in 2017) [2]. School failure is associated with a poorly qualified labor force and low wages, both of which increase the risk of social exclusion and criminality [3]. Hence, modern socioemotional approaches combine formal subjects with socioemotional learning [4]. This study shows how including an emotional education program in the school curriculum can affect long-term educational sustainability for children from families with a low socioeconomic status.

The article has the following structure. The next section reviews the literature covering three elements: the socioeconomic status of the family, parents' educational level, and the primary education curriculum in Spain. The third section describes the experimental procedure and presents the results. Finally, the implications and conclusions of the study are discussed.

\section{Literature Review}

This section examines the socioeconomic status of the family, parents' educational level, and the curricular structure of primary education in Spain. The socioeconomic status (SES) of the family and 
parents' educational attainment are two variables that define the social and economic factors of young students' development.

\subsection{Families' Socioeconomic Status}

SES describes a person or a family according to the parents' education, wealth, and occupation [5]. SES determines the family's socioeconomic status [6]. SES is a multidimensional concept based on three assumptions. First, families have different and unequal positions within the social structure. Second, the main indicators of social status are an individual's formal education, occupation, gender, and marital status. Third, the combination of these indicators determines the social status of people and families [7].

Authors have focused on education, occupation, income, and resources within the family unit [6]. Parents' education is one of the most stable factors of SES because it is acquired early and remains stable throughout adult life. Education and occupation are linked to wages and home resources. These resources include possessions (e.g., houses and books) and access to services, particularly education services for children $[5,8]$.

Family status also determines other factors that affect children's development. Such factors include neighborhood, neighbors, lifestyle, and access to complementary education services (e.g., gym, libraries, and green areas), which indirectly provide supportive relationships that foster social norms and shared values [9]. Thus, while a person's development is influenced by family, it is also influenced by family relationships and family members' relationships with other environments (work, friends, and neighbors) within a society and culture $[10,11]$.

Studies have shown a correlation between low social status and unhealthy lifestyles such as poor diet, limited sporting activity, high rates of chronic diseases, and sight or hearing problems [12]. Low social status is also related to a tendency to engage in risky behaviors [13], difficulties in accessing health services, and scarce knowledge about the consequences of unhealthy behavior. In conclusion, low social status is broadly associated with poor living standards and high psychological stress [14]. Similarly, low SES has been linked to negative attitudes toward school, high school absenteeism, low educational attainment, and low access to specialized higher education $[15,16]$.

\subsection{Parents' Educational Attainment}

In today's globalized world, where a technological revolution is underway, educating individuals is essential. Through the acquisition of knowledge and skills, an academic education provides opportunities for people to lead a better life and develop human capital. Hence, education can help fight poverty [17,18].

Parents' educational attainment is also related to social status and children's education. Studies have shown that parents' educational attainment is closely related to children's academic success and educational level $[19,20]$. Parents with higher educational attainment feel more capable of helping their children, are more aware of academic performance, and are more prone to monitoring their children's academic progress [21]. In contrast, the parents' occupation is not significantly related to children's academic performance [19].

\subsection{Effects on Preadolescents and Adolescents}

A low SES is positively related to externalized and internalized behavioral problems [22]. This link may be relevant during preadolescence, which is the target age group covered by this study. During preadolescence and adolescence, boys and girls demand higher autonomy [23]. Parents with low-skilled occupations tend to have longer working hours. Accordingly, their children spend more time without direct parental control, and thus have more freedom and autonomy than is expected for children of their age. Studies have shown that children belonging to low social strata are more prone to having deviant behaviors and associating with other children of similar age and behavior [24]. These factors increase rejection by less conflictive peers [25-27]. 
Teenagers are also immersed in their academic studies, which require long-term effort and exert pressure to achieve good results. There is also greater estrangement between teenagers and parents because of long working hours, which increase the time teenagers spend alone at home [28]. Less monitoring of children encourages children to develop low-effort, satisfying behaviors such as surfing the Internet, spending long hours on the computer, and entering and leaving the home uncontrolled, which is an inherently high-risk behavior.

Breakup or divorce may also imply longer working hours, thereby affecting parents' monitoring of children. Divorce is associated with a decrease in wealth (and with poverty), changes at home and school, and alterations in social support systems [29]; all of which increase the risks facing family members, especially children.

In sum, adolescents belonging to low SES have a higher risk of associating with rebellious children [22] and experimenting with alcohol and marijuana at an earlier age than children of higher social status [30]. These children also have a greater tendency to develop challenging behaviors [31,32].

\subsection{Curricular Structure of Primary Education in Spain}

In Spain, Law 8/2013 of 9 December on improving education quality, and Law 2/2006 of 3 May on education, [33,34] govern primary education over six school years (children aged 6 to 12 years, not including grade repetitions). The academic goals aim at building know-how, which enables the application of educational contents. Achieving these objectives is expected to help children obtain the knowledge, skills, abilities, and attitudes required to successfully continue into secondary education.

The education legislation itself defines competencies as the skills needed to apply and understand academic contents and address complex problems. Accordingly, the education legislation covers the following competencies: linguistic communication, mathematics, basic science and technology skills, digital competencies, learning to learn, social and civic competencies, initiative and entrepreneurial spirit, and cultural conscience and expression.

Primary education in Spain has main modules, specific modules, and regional modules. These regional modules vary across autonomous regions. The main modules are Natural Sciences, Social Sciences, Language and Literature, Mathematics, and First Foreign Language. The specific modules are Arts, Physical Education, Co-official Language of the Autonomous Region (in this case, Valencian), and the family or legal tutors' choice of Religion, or Social and Civic Values [35]. One or two additional modules are chosen according to the needs of the school [36]. The Spanish school curriculum is not written in gender-neutral language. Furthermore, programs for the education of emotions are not included alongside other programs that relate to mixed education and gender equality.

We designed an emotional education program as one of these additional modules. This program consisted of 16 lessons, each of which lasted approximately two hours. The content of the program was as follows:

(1) Emotion knowledge and management: training positive and negative emotions towards oneself and others, self-control.

(2) Self-regulation of emotions and personal autonomy: positive/negative attitudes; self-esteem; responsibility, self-regulation, and self-motivation, training emotional awareness. Awareness of one's own emotions can help reveal the emotions of others [37].

(3) Communication skills: emotional and contextual abilities, assertiveness, communication, expression of ideas. Thanking and asking for favors, expressing complaints, active listening, and empathy and prosocial behavior, listening to other people's feelings.

(4) Effective confrontation and social settlement skills: identifying cohabitation problems, problem-solving, and negotiation techniques for solving conflicts. 


\subsection{Objectives and Hypotheses}

We analyzed the extent of students' disruptive behaviors (aggression), and the effect of emotional education programs during childhood. Accordingly, the goals of this study were as follows: (1) to analyze the degree of childhood aggression in children from low social strata and the effects of socioemotional programs on children's aggression; (2) to compare the results of the program by children's gender, age, family structure, parents' educational attainment, and social status.

The following hypotheses were tested:

(1) The socioemotional education program reduces aggression in children.

(2) This reduction in aggression holds for all sociological variables under analysis: gender, age, family structure, maternal and paternal educational attainment, and social status.

\section{Method}

\subsection{Participants}

Participants were 413 children (55.2\% boys and $44.8 \%$ girls), aged 7 to 12 years $(M=9.12$; $\mathrm{SD}=1.52)$. Children attended public schools in the metropolitan area of Valencia. They were enrolled in grades 2 through 6 (primary education). Most families were of Spanish origin (81.8\%), while $18.2 \%$ were originally from Western Europe, Eastern Europe, Arab countries, Sub-Saharan Africa, and South-East Asia. In terms of family structure, $83.8 \%$ belonged to two-parent families, $11.1 \%$ belonged to stepfamilies, and $5.1 \%$ belonged to single-parent families due to either divorce or death. The distribution for paternal educational attainment was as follows: no primary education $(19.8 \%)$, primary education (59.6\%), and Baccalaureate or higher vocational training (20.6\%). The distribution for maternal educational level was as follows: no primary education $(15.5 \%)$, primary education $(63.0 \%)$, Baccalaureate or higher vocational training $(19.1 \%)$, and university education $(2.4 \%)$. All parents belonged to low social strata (IV and V): $72.2 \%$ belonged to social class IV, and $27.8 \%$ belonged to social class V.

\subsection{Instruments}

Children's Sociodemographic Profile. Sociodemographic variables were gender, age, family structure, parents' educational attainment (mother and father separately), and social class. Family structure categories were (1) two-parent families; (2) stepfamilies: one parent had a stable relationship with another adult who may or may not have children from previous relationships; and (3) single-parent families: families with one parent. Educational attainment of the parents had four categories: (1) attended school but did not graduate; (2) graduated from school; (3) completed non-compulsory secondary education (Baccalaureate or vocational training); and (4) obtained a university degree. Social status was classified according to Hollingshead's four factor index of social status [7]. This index reflects parents' educational level and occupation. The combined score for both parents (two-parent families) or for one parent (single-parent families) determined the social status of the family. Hollingshead's index yields five levels of social status: I High, II Upper-middle, III Middle, IV Lower-middle, and V Low.

Physical and Verbal Aggression Scale (AFV) [38,39]. The scale has 15 items that assess physical and verbal aggression toward others. Each item has three possible responses $(3=$ usually, $2=$ sometimes, $1=$ never) to indicate the frequency with which a specific behavior occurs. Accordingly, higher scores indicate greater aggression. Example items are, "I kick and punch" and "I speak badly about my classmates". Cronbach's alpha was 0.85 .

\subsection{Procedure}

The project was presented in public schools in the metropolitan area of Valencia, Spain. Schools were located in areas where students were at social risk. The program required teachers' 
commitment to work with students. Teachers therefore attended a training seminar, which took place at the school. The four public schools that participated in the study were located in peripheral, problematic areas of the city, where $20 \%$ of students were immigrants or ethnic or cultural minorities (e.g., of African or gypsy origin). Participation was voluntary. Permission from families and the Valencian government were obtained. Student assessment was rigorous, and respected students' right to anonymity and confidentiality. The ethical principles set forth in the Helsinki Act (1975) and later adaptations were observed.

The project had four stages. (1) Teacher training consisted of $10 \mathrm{~h}$ of training before the program and one hour per fortnight after the program had started (24 h in total). (2) Pre-test assessment was conducted to measure students' physical and verbal aggression using the standardized psychometric test ([38], Spanish version 39). (3) Teachers implemented the program in class (content reflected in Table 1). (4) Post-test assessment was conducted using the same aggression questionnaire as for the pre-test assessment. SPSS version 21.0 was used for the statistical analyses.

Table 1. Summary of research phases in the control and experiment groups.

\begin{tabular}{|c|c|c|c|}
\hline Group & Pre-Test (T1) & Intervention-Program Content & Post-Test (T2) \\
\hline $\begin{array}{l}\text { Training } \\
\text { group }\end{array}$ & $\begin{array}{l}\text { - Physical and Verbal } \\
\text { Aggression Scale } \\
\text { - } \quad \text { Emotional } \\
\text { Instability Scale } \\
\text { - } \quad \text { Prosocial } \\
\text { Behavior Scale }\end{array}$ & $\begin{array}{l}\text { - Subjects on the curriculum } \\
\text { Emotional education } \\
\text { intervention program } \\
\text { - } \quad \begin{array}{l}\text { Knowledge and } \\
\text { management of emotions }\end{array} \\
\text { - } \quad \text { Self-regulation of emotions } \\
\text { - } \text { and personal autonomy } \\
\text { - } \quad \text { Effective coping skills and } \\
\quad \text { daily problem solving }\end{array}$ & $\begin{array}{l}\text { - Physical and Verbal } \\
\text { Aggression Scale } \\
\text { - Emotional } \\
\text { Instability Scale } \\
\text { - Prosocial } \\
\text { Behavior Scale }\end{array}$ \\
\hline $\begin{array}{l}\text { Control } \\
\text { group }\end{array}$ & $\begin{array}{l}\text { Same instruments as for } \\
\text { experimental group }\end{array}$ & Subjects on the curriculum & $\begin{array}{l}\text { Same instruments as for } \\
\text { experimental group }\end{array}$ \\
\hline
\end{tabular}

\subsection{Data Analysis}

The Kolmogorov-Smirnov test [40] was used to determine the goodness of fit between two probability distributions. The results supported the use of non-parametric tests for the analyses (the significance of the Kolmogorov-Smirnov test was less than 0.05).

Analyses were performed to determine the effects of the socioemotional education program. First, the Mann-Whitney U test [41] was used to check the equivalence of the population of boys and girls. The $\mathrm{U}$ test was complemented by the Rosenthal $r$ analysis of effect size. The Rosenthal $r$, known as the counternull value, is calculated by dividing the Z-score by the square root of $\mathrm{N}$. It is suitable for non-parametric testing [42]. Second, we performed the Wilcoxon sign test, which we applied to related samples assessed at two different times (pre-test vs. post-test) [43]. We combined this test with the corresponding effect size analysis. The sign test was applied to the population, which was distributed according to sociodemographic variables: gender, age, family structure, social status, and educational attainment of both parents.

\section{Results}

We first conducted descriptive analysis of students' physical and verbal aggression in the pre-test and post-test stages. Table 2 shows higher aggression values in the pre-test phase. The results were slightly skewed to the right, and were more pronounced than those in the post-test phase. The minimum aggression values were the same in both stages, but the top values were higher in the 
pre-test stage ( 3.00 pre-test vs. 2.20 post-test). These results indicate that aggression was reduced following the program. They also indicate that fewer children had high rates of aggression.

Table 2. Descriptive analysis of physical and verbal aggression before and after the emotional education program.

\begin{tabular}{ccccccc}
\hline Test & Mean & $\begin{array}{c}\text { Standard } \\
\text { Deviation }\end{array}$ & Asymmetry & Kurtosis & Min. & Max. \\
\hline Pre-test physical and verbal aggression & 1.43 & 0.38 & 1.24 & 1.54 & 1.00 & 3.00 \\
Post-test physical and verbal aggression & 1.31 & 0.26 & 0.70 & -0.35 & 1.00 & 2.20 \\
\hline
\end{tabular}

The Mann-Whitney U test [41] was used to test for equivalence of the population of boys and girls. The results reveal no significant differences between boys' and girls' aggression pre-test, although boys tended to have higher scores. Significant differences were observed in the post-test results, where boys were found to be more aggressive than girls. Effect size was low (Rosenthal $r=0.262$ ) (Table 3) [42].

Table 3. Pre-test and post-test comparative analysis of verbal and physical aggression by gender.

\begin{tabular}{|c|c|c|c|c|c|c|c|c|}
\hline \multirow{2}{*}{ Test } & \multirow{2}{*}{$\mathbf{N}$} & \multicolumn{2}{|c|}{ Boys } & \multicolumn{2}{|c|}{ Girls } & \multirow{2}{*}{$Z$} & \multirow{2}{*}{$\begin{array}{c}\text { Asymptotic } \\
\text { Significance (Bilateral) }\end{array}$} & \multirow{2}{*}{$\begin{array}{l}\text { Rosenthal } r=\text { abs } \\
\quad(\mathrm{Z} / \operatorname{Root}[\mathrm{N}])\end{array}$} \\
\hline & & $\mathbf{M}$ & SD & $\mathbf{M}$ & SD & & & \\
\hline Pre-test & 413 & 1.47 & 0.42 & 1.38 & 0.32 & -0.152 & 0.124 & 0.007 \\
\hline Post-test & 413 & 1.35 & 0.28 & 1.25 & 0.22 & -3.30 & 0.001 & 0.262 \\
\hline
\end{tabular}

Table 4 shows the results of the analysis comparing pre-test and post-test scores using the Wilcoxon test for related samples. Children's aggression was significantly lower following the program. This significant reduction occurred in boys and girls. The effect size was medium to medium-high (Rosenthal $r=0.305$ and 0.443 for boys and girls, respectively).

We observed significant differences between the pre-test and post-test stages in all ages, except for the youngest children (aged 7 years). At this age, the results reveal a negative trend, but differences were non-significant (asymptotic significance $=0.177$ ). For the remaining ages $(8-12$ years), differences between pre-test and post-test stages were significant, with a clear reduction in aggression at all ages. The effect size was medium-high to high (Rosenthal $r$ between 0.370 and 0.611 for all ages).

Table 4. Comparative analysis of verbal and physical aggression in the pre-test and post-test stages by sociodemographic variables (entire population).

\begin{tabular}{|c|c|c|c|c|c|c|c|c|}
\hline \multirow{2}{*}{ Verbal and Physical Aggression } & \multirow{2}{*}{$\mathbf{N}$} & \multicolumn{2}{|c|}{ Pre-Test } & \multicolumn{2}{|c|}{ Post-Test } & \multirow{2}{*}{$Z$} & \multirow{2}{*}{$\begin{array}{c}\text { Asymptotic } \\
\text { Significance } \\
\text { (Bilateral) }\end{array}$} & \multirow{2}{*}{$\begin{array}{c}\text { Rosenthal } r=\text { abs } \\
\text { (Z/Root }[N])\end{array}$} \\
\hline & & $\mathbf{M}$ & SD & $\mathbf{M}$ & SD & & & \\
\hline Physical and verbal aggression & 413 & 1.43 & 0.38 & 1.31 & 0.26 & -7.43 & 0.000 & 0.366 \\
\hline \multicolumn{9}{|l|}{ Gender } \\
\hline Boys & 228 & 1.47 & 0.42 & 1.35 & 0.28 & -4.60 & 0.000 & 0.305 \\
\hline Girls & 185 & 1.38 & 0.32 & 1.25 & 0.22 & -6.03 & 0.000 & 0.443 \\
\hline \multicolumn{9}{|l|}{ Age } \\
\hline 7 & 79 & 1.29 & 0.40 & 1.23 & 0.25 & -1.35 & 0.177 & 0.152 \\
\hline 8 & 85 & 1.44 & 0.38 & 1.33 & 0.26 & -3.41 & 0.001 & 0.370 \\
\hline 9 & 67 & 1.46 & 0.41 & 1.33 & 0.28 & -3.53 & 0.000 & 0.431 \\
\hline 10 & 91 & 1.49 & 0.34 & 1.35 & 0.25 & -3.65 & 0.000 & 0.383 \\
\hline 11 & 70 & 1.41 & 0.33 & 1.29 & 0.23 & -3.50 & 0.000 & 0.418 \\
\hline 12 & 21 & 1.58 & 0.40 & 1.33 & 0.25 & -2.80 & 0.005 & 0.611 \\
\hline \multicolumn{9}{|l|}{ Family structure } \\
\hline Two-parent families & 346 & 1.41 & 0.36 & 1.30 & 0.26 & -7.09 & 0.000 & 0.381 \\
\hline Stepfamilies & 46 & 1.43 & .34 & 1.32 & 0.23 & -2.24 & 0.005 & 0.330 \\
\hline Single-parent families & 21 & 1.50 & 0.45 & 1.35 & 0.25 & -2.62 & 0.009 & 0.572 \\
\hline
\end{tabular}


Table 4. Cont.

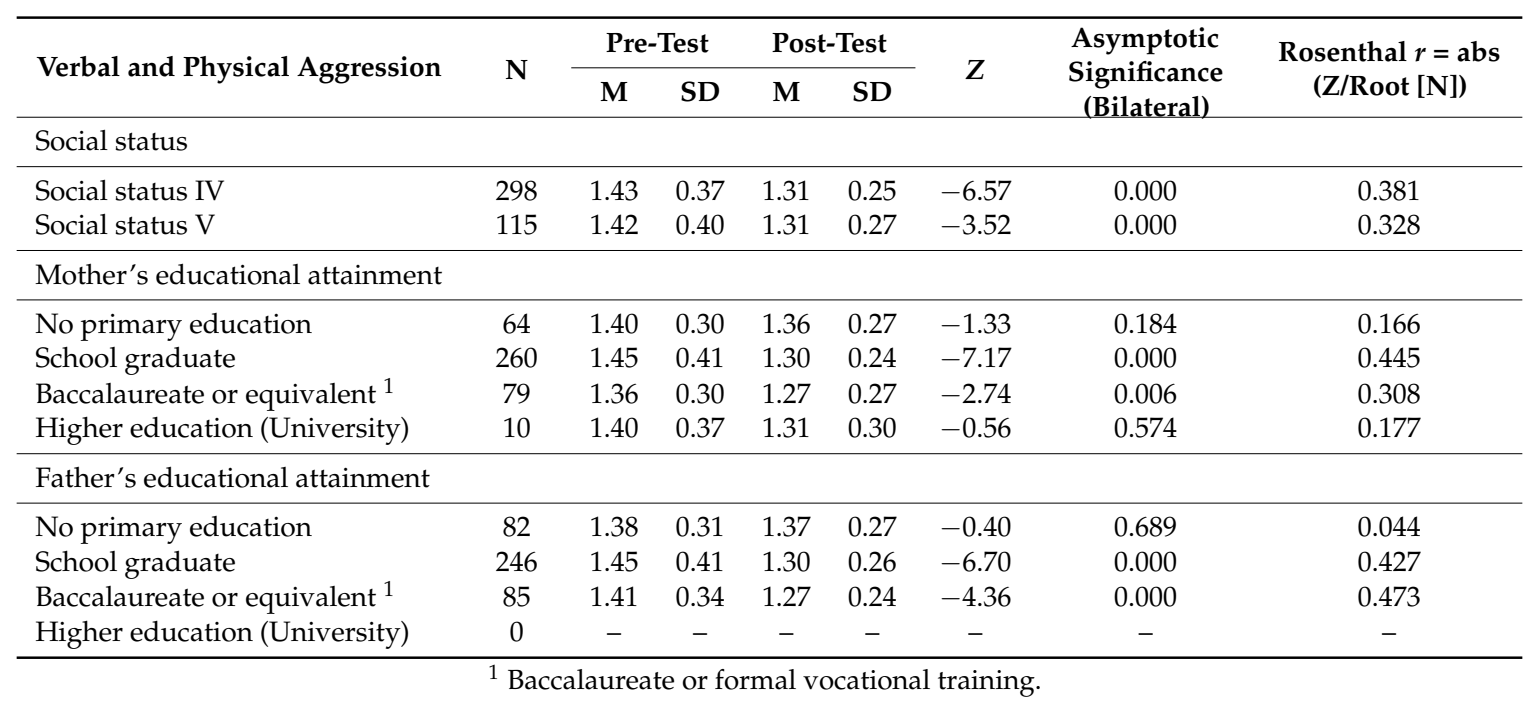

For the family variables (i.e., family structure, parents' educational attainment, and social status), Table 4 shows a reduction in aggression among children belonging to two-parent families, stepfamilies, and single-parent families, with significant differences in all cases. The effect size was medium to high (Rosenthal $r=0.381,0.330$, and 0.572 for two-parent families, stepfamilies, and single-parent families, respectively). The situation was the same for children belonging to social classes IV and V. Aggression was significantly lower following the emotional education program. The effect size was medium (Rosenthal $r=0.381$ and 0.328 for social classes IV and V, respectively). The effect size was medium to medium-high, with a Rosenthal $r$ of 0.308 for mothers with Baccalaureate or formal vocational training and 0.473 for fathers with Baccalaureate or formal vocational training. The effect size values confirm the strength of the results, thereby offering hope for reducing aggressive behaviors among at-risk children.

The results by paternal educational level were less conclusive, although boys' aggression scores decreased between the pre-test and post-test phases. For children whose mothers did not finish school and children whose mothers had a university education, differences between the pre-test and post-test phases were non-significant, although aggression tended to decrease in both cases. This absence of a significant difference may be because the two groups were small (64 mothers who did not finish school and 10 mothers who had a university education). In contrast, there were significant differences in the aggression of children whose mothers were school graduates, and children whose mothers had completed the Baccalaureate or similar.

A similar finding was observed when comparing pre-test and post-test scores for aggression among children whose fathers graduated from school or completed the Baccalaureate or similar. For children whose fathers completed the Baccalaureate, the difference between pre-test and post-test scores was significant. Children had lower scores for aggression after taking the emotional education program. Seemingly, the educational level of both parents can enhance the effects of the emotional education program, and reduce aggression among children. Nevertheless, it would be useful to analyze this situation for a larger population with parents who completed a university education.

\section{Discussion and Conclusions}

The analysis indicates that aggression among children belonging to low socioeconomic status families is moderate. Boys were observed to be slightly more aggressive than girls, mainly at the post-test stage. The program seems to have positively affected both groups. The average aggression scores were lower in the post-test stage than in the pre-test stage. The effects were greater for girls 
than boys. The results are consistent with previous studies showing that men have higher aggression scores than women do in childhood and adolescence [44,45].

The results show that the program had positive effects on boys and girls. Physical and verbal aggression was reduced in boys and girls (Hypothesis 1). Note that emotional learning is related to a lower level of aggressive and maladaptive behaviors [46].

The results are also highly positive in terms of sociodemographic variables and the effects of the program. The program had positive effects on children belonging to most of the variable groups under study: different types of families (two-parent families, stepfamilies, and single-parent families), and social strata IV and V. The program also had a positive effect across most age groups and parental educational attainment groups. However, the program was not as successful among the youngest children (aged 7 years), nor among children whose mothers had no studies or university studies or whose fathers had no studies. The results for the remaining groups were highly positive. Children's aggression rates were significantly reduced following the program (Hypothesis 2).

Aggressive people usually have tense, awkward relationships with others. They tend to relate to peers who have similar behaviors, and they tend to be rejected by less conflictive peers [25]. These tendencies may increase their vulnerability. The effects of belonging to low socioeconomic strata (in terms of neighborhood, restricted access to services, long working hours of parents, low adult monitoring, excessive autonomy, and a tendency toward low-effort activities, and therefore higher dropout risk) indicate that efforts in improving children's development through socioemotional education programs from an early age are worthwhile. This study yields promising results. The findings stress how developing socioemotional skills can affect interpersonal relationships, which can in turn reduce aggression in the long term. Aggressive children have low self-control [44,47], a high tendency to behave impulsively [45,48], and difficulties in developing resilience [49]. These traits contribute to problems with the environment and ineffective behaviors. Conversely, learning emotional skills encourages positive development and personal strengthening strategies [50], which lead to more open and expressive behavior [51].

In summary, creating emotional education programs that are imparted by teachers as part of the curriculum is a valuable initiative. The goal of primary school is to provide a well-rounded education and foster healthy relations among children. During childhood, reducing aggression lays the foundations for harmonious relations at school.

These encouraging results are not without limitations. The first limitation refers to the cross-sectional nature of the study. Validation through a longitudinal study would strengthen the results, enabling analysis at different times and over longer periods. Secondly, the study is based on children's self-reported data. Despite this limitation, studies have confirmed the reliability of results based on children's self-reported data. These data are sometimes more suitable than data provided by adults because children are less conditioned by social desirability [50,52].

Author Contributions: Ana Tur-Porcar and Elisabeth Malonda Vidal conceived, designed and performed the experiments; Ana Tur-Porcar, and Elisabeth Malonda Vidal and Alicia Mas-Tur analyzed the data; Alicia Mas-Tur contributed reagents/materials/analysis tools; Ana Tur-Porcar and Alicia Mas-Tur wrote the paper.

Conflicts of Interest: The authors declare no conflict of interest.

\section{References}

1. Ministerio De Educación, Cultura Y Deporte. Informe 2016 Sobre El Estado Del Sistema Educativo. Curso 2014-2015; Ministerio De Educación, Cultura Y Deporte, Consejo De Estado DE Educación: Madrid, Spain, 2016. Available online: http://www.mecd.gob.es/educacion/mc/cee/publicaciones/informes-del-sistemaeducativo/informe-2016.html (accessed on 23 August 2017).

2. Instituto Nacional De Estadística (INE). Encuesta De Población Activa; INE: Madrid, Spain, 2017; Available online: http:/ / www.ine.es/prensa/epa_tabla.htm (accessed on 23 August 2017).

3. Wilson, D.B.; Gottfredson, D.C.; Najaka, S.S. School-based prevention of problem behaviors: A meta-analysis. J. Quant. Criminol. 2001, 17, 247-272. [CrossRef] 
4. Jones, S.M.; Brown, J.L.; Aber, J.L. Two-year impacts of a universal school-based social-emotional and literacy intervention: An experiment in translational developmental research. Child Dev. 2011, 82, 533-554. [CrossRef] [PubMed]

5. Hauser, R.M. Measuring socioeconomic status in studies of child development. Child Dev. 1994, 65, 1541-1545. [CrossRef] [PubMed]

6. Sirin, S.R. Socioeconomic status and academic achievement: A meta-analytic review of research. Rev. Educ. Res. 2005, 75, 417-453. [CrossRef]

7. Hollingshead, A.B. Four factor index of social status. Yale J. Sociol. 2011, 8, 21-52.

8. McLoyd, V. Socioeconomic disadvantage and child development. Am. Psychol. 1998, 53, 185-204. [CrossRef] [PubMed]

9. Bradley, R.H.; Corwyn, R.F. Socioeconomic status and child development. Annu. Rev. Psychol. 2002, 53, 371-399. [CrossRef] [PubMed]

10. Bronfenbrenner, U. Ecology of the family as a context for human development: Research perspectives. Dev. Psychol. 1986, 22, 723-742. [CrossRef]

11. Bronfenbrenner, U.; Morris, P.A. The bioecological model of human development. In Handbook of Child Psychology, 6th ed.; Lerner, R.M., Damon, W., Eds.; John Wiley: Hoboken, NJ, USA, 2006; pp. 793-828.

12. Koster, A.; Bosma, H.; van Lenthe, F.J.; Kempen, G.I.; Mackenbach, J.P.; van Eijk, J.T. The role of psychosocial factors in explaining socio-economic differences in mobility decline in a chronically ill population: Results from the GLOBE study. Soc. Sci. Med. 2005, 61, 123-132. [CrossRef] [PubMed]

13. Wardle, J.; Jarvis, M.J.; Steggles, N.; Sutton, S.; Williamson, S.; Fairmond, H.; Cartwright, M.; Simon, A.E. Socioeconomic disparities in cancer-risk behaviors in adolescence: Baseline Results from the Health and Behavior in Teenagers Study. Prev. Med. 2003, 36, 721-730. [CrossRef]

14. Chen, E.; Matthews, K.A.; Boyce, W.T. Socioeconomic differences in children's health: How and why do these relationships change with age? Psychol. Bull. 2002, 128, 295-329. [CrossRef] [PubMed]

15. DeGarmo, D.S.; Forgatch, M.S.; Martinez, C.R. Parenting of divorced mothers as a link between social status and boys' academic outcomes: Unpacking the effects of socioeconomic status. Child Dev. 1999, 70, 1231-1245. [CrossRef] [PubMed]

16. Battin-Pearson, S.; Newcomb, M.D.; Abbott, R.D.; Hill, K.G.; Catalano, R.F.; Hawkins, J.D. Predictors of early high school drop-out: A test of five theories. J. Educ. Psychol. 2000, 92, 568-582. [CrossRef]

17. Battle, J.; Lewis, M. The increasing significance of class: The relative effects of race and socioeconomic status on academic achievement. J. Poverty 2002, 6, 21-35. [CrossRef]

18. Salvioni, D.M.; Franzoni, S.; Cassano, R. Sustainability in the Higher Education System: An Opportunity to Improve Quality and Image. Sustainability 2017, 9, 914. [CrossRef]

19. Farooq, M.S.; Chaudhry, A.H.; Shafiq, M.; Berhanu, G. Factors affecting students' quality of academic performance: A case of secondary school level. J. Qual. Technol. Manag. 2011, 7, 1-14.

20. Bieler, A.; McKenzie, M. Strategic planning for sustainability in Canadian higher education. Sustainability 2017, 9, 161. [CrossRef]

21. Azhar, M.; Nadeem, S.; Naz, F.; Perveen, F.; Sameen, A. Impact of parental education and socio-economic status on academic achievements of university students. Eur. J. Psychol. Res. 2014, 1, 1-9.

22. Moss, H.B.; Lynch, K.G.; Hardie, T.L. Affiliation with deviant peers among children of substance dependent fathers from pre-adolescence into adolescence: Associations with problem behaviors. Drug Alcohol Depend. 2003, 71, 117-125. [CrossRef]

23. Morris, A.S.; Silk, J.S.; Steinberg, L.; Myers, S.S.; Robinson, L.R. The role of the family context in the development of emotion regulation. Soc. Dev. 2007, 16, 361-388. [CrossRef] [PubMed]

24. Chen, D.; Drabick, D.A.; Burgers, D.E. A Developmental Perspective on Peer Rejection, Deviant Peer Affiliation, and Conduct Problems Among Youth. Child Psychiatry Hum. Dev. 2015, 46, 823-838. [CrossRef] [PubMed]

25. Dishion, T.J. An evolutionary framework for understanding coercion and aggression. In Oxford Handbook of Coercive Relationship Dynamics; Dishion, T.J., Snyder, J.J., Eds.; Oxford University Press: New York, NY, USA, 2016; pp. 53-68.

26. Dishion, T.J.; Ha, T.; Véronneau, M.-H. An ecological analysis of the effects of deviant peer clustering on sexual promiscuity, problem behavior, and childbearing from early adolescence to adulthood: An enhancement of the Life History Framework. Dev. Psychol. 2012, 48, 703-717. [CrossRef] [PubMed] 
27. Shephard, K.; Brown, K.; Guiney, T. Researching the Professional-Development Needs of Community-Engaged Scholars in a New Zealand University. Sustainability 2017, 9, 1249. [CrossRef]

28. Luthar, S.S.; Latendresse, S.J. Children of the affluent: Challenges to well-being. Curr. Dir. Psychol. Sci. 2005, 14, 49-53. [CrossRef] [PubMed]

29. Forgatch, M.S.; Snyder, J.J.; Patterson, G.R.; Pauldine, M.R.; Chaw, Y.; Elish, K.; Harris, J.B.; Richardson, E.B. Resurrecting the chimera: Progressions in parenting and peer processes. Dev. Psychopathol. 2016, 28, 689-706. [CrossRef] [PubMed]

30. Fothergill, K.E.; Ensminger, M.E. Childhood and adolescent antecedents of drug and alcohol problems: A longitudinal study. Drug Alcohol Depend. 2006, 82, 61-76. [CrossRef] [PubMed]

31. Snyder, J.J.; Schrepferman, L.; McEachern, A.; Barner, S.; Johnson, K.; Provines, J. Peer deviancy training and peer coercion: Dual processes associated with early-onset conduct problems. Child Dev. 2008, 79, 252-268. [CrossRef] [PubMed]

32. Rieh, S.Y.; Lee, B.Y.; Oh, J.G.; Schuetze, T.; Porras Álvarez, S.; Lee, K.; Park, J. Integration of Sustainability into Architectural Education at Accredited Korean Universities. Sustainability 2017, 9, 1121. [CrossRef]

33. Jefatura Del Estado. Ley Orgánica 2/2006, De 3 De Mayo, De Educación. Boletín Oficial Del Estado, Núm. 106. De 4 De Mayo De 2006. 2006. Available online: https:/ /www.boe.es/buscar/pdf/2006/BOE-A-20067899-consolidado.pdf (accessed on 14 February 2017).

34. Jefatura Del Estado. Ley Orgánica 8/2013, De 9 De Diciembre, Para La Mejora De La Calidad Educativa. Boletín Oficial Del Estado, 10 De Diciembre De 2013. 2013. Available online: https:/ / www.boe.es/boe/dias / 2013/12/10/pdfs/BOE-A-2013-12886.pdf (accessed on 14 February 2017).

35. Ministerio De Educación, Cultura Y Deporte (2014). Real Decreto 126/2014, De 28 De Febrero, Por El Que Se Establece El Currículo Básico De La Educación Primaria. Boletín Oficial Del Estado, 1 Marzo 2014. Available online: https:/ / www.boe.es/boe/dias/2014/03/01/pdfs/BOE-A-2014-2222.pdf (accessed on 14 February 2017).

36. Decreto 108/2014, de 4 de Julio, del Consell, por el Que Establece el Currículo y Desarrolla la Ordenación General de la Educación Primaria en la Comunitat Valenciana [2014/6347] (Diari Oficial Núm. 7311 de 07.07.2014). Available online: http://www.dogv.gva.es/datos/2014/07/07/pdf/2014_6347.pdf (accessed on 7 September 2017).

37. Rieffe, C.; De Rooij, M. The longitudinal relationship between emotion awareness and internalising symptoms during late childhood. Eur. Child Adolesc. Psychiatry 2012, 21, 349-356. [CrossRef] [PubMed]

38. Caprara, G.V.; Pastorelli, C. Early emotional instability, prosocial behavior, and aggression: Some methodological aspects. Eur. J. Personal. 1993, 7, 19-36. [CrossRef]

39. Del Barrio, M.V.; Moreno, C.; López, R. Evaluación de la agresión e inestabilidad emocional en niños españoles y su relación con la depression [Assessment of Agression and emotional instability in Spanish children: Its relationship with depression]. Clin. Y Salud 2001, 12, 33-50.

40. Gibbons, J.D.; Chakraborti, S. Nonparametric Statistical Inference, 3rd ed.; Dekker: New York, NY, USA, 1992.

41. Mann, H.B.; Whitney, D.R. On a test of whether one of two random variables is stochastically larger than the other. Ann. Math. Stat. 1947, 18, 50-60. [CrossRef]

42. Rosenthal, R. Parametric measures of effect size. In The handbook of Research Synthesis; Cooper, H., Hedges, L.V., Eds.; Russell Sage Foundation: New York, NY, USA, 1994; pp. 231-244.

43. Riffenburgh, R.H. Statistics in Medicine; Academic Press: London, UK, 1999.

44. Berger, K.S. Update on bullying at school: Science forgotten? Dev. Rev. 2007, 27, 90-126. [CrossRef]

45. Mestre, M.V.; Tur, A.M.; Samper, P.; Latorre, A. Inestabilidad emocional y agresividad: Factores Predictores [Emotional instability and aggressiveness: Predicting factors]. Ansiedad Estrés 2010, 16, 33-45.

46. Wilson, S.J.; Lipsey, M.W. School-based interventions for aggressive and disruptive behavior: Update of a meta-analysis. Am. J. Prev. Med. 2007, 33, 130-143. [CrossRef] [PubMed]

47. Eisenberg, N.; Sulik, M.J. Emotion-related self-regulation in children. Teach. Psychol. 2012, 39, 77-83. [CrossRef] [PubMed]

48. Olweus, D. Bully/victim problems among schoolchildren: Basic facts and effects of a school based intervention program. In The Development and Treatment of Childhood Aggression; Pepler, J.D., Rubin, K.H., Eds.; Lawrence Erlbaum Associates, Inc.: Hillsdale, NJ, USA, 1991; Chapter xvii; pp. 411-448. 
49. Masten, A.S.; Wright, M.O.D. Resilience over the lifespan: Developmental perspectives on resistance, recovery, and transformation. In Handbook of Adult Resilience; Reich, J.W., Zautra, A.J., Hall, J.S., Eds.; Guilford: New York, NY, USA, 2009; pp. 213-237.

50. Catalano, R.F.; Berglund, M.L.; Ryan, J.A.M.; Lonczak, H.S.; Hawkins, J.D. Positive youth development in the United States: Research findings on evaluations of positive youth development programs. Ann. Am. Acad. Political Soc. Sci. 2004, 591, 98-124. [CrossRef]

51. Izard, C.E.; King, K.A.; Trentacosta, C.J.; Morgan, J.K.; Laurenceau, J.P.; Krauthamer-Ewing, E.S.; Finlon, K.J. Accelerating the development of emotion competence in Head Start children: Effects on adaptive and maladaptive behavior. Dev. Psychopathol. 2008, 20, 369-397. [CrossRef] [PubMed]

52. Dijkstra, W.; Smit, J.H.; Comijs, H.C. Using social desirability scales in research among the elderly. Qual. Quant. 2001, 35, 107-115. [CrossRef]

(C) 2017 by the authors. Licensee MDPI, Basel, Switzerland. This article is an open access article distributed under the terms and conditions of the Creative Commons Attribution (CC BY) license (http://creativecommons.org/licenses/by/4.0/). 